\title{
Analysis Of Bankruptcy Law Provisions In New Member EU Countries: Global Competitive Strategy Implications For Multinational Corporations
}

\author{
F. J. Brewerton, (Email: brewerton@panam.edu), University of Texas Pan American
} Jane LeMaster, (Email: jlemaster@panam.edu), University of Texas Pan American

\begin{abstract}
Globalization has been responsible for a number of ongoing interrelated trends including an accelerated worldwide movement toward economic integration, an ongoing proliferation of new multinational corporations, a widening search for new economic opportunities by multinational corporations, and an increasing concern for and attention to bankruptcy as a contingency strategy for multinational corporations when primary strategies catastrophically fail. The economic benefits associated with the removal of trade barriers is also attracting new member countries to the EU and other trading blocks but these new member countries' bankruptcy law provisions may have uncertain contingency strategy implications for MNC's.
\end{abstract}

This paper comprises (1) a brief summary of the general trends associated with globalization; (2) a discussion of why international bankruptcy law is becoming increasingly important in the formulation of contingency strategy in multinational corporations; (3) a discussion and analysis of bankruptcy law provisions in new EU member states; (4) a discussion of the strategic implications associated with new member states' bankruptcy laws; and (5) general conclusions regarding the attractiveness of new member states' bankruptcy laws to multinational corporation strategists.

\section{Introduction}

lobalization may be defined as a progression away from a world in which national economies were isolated from each other by barriers to cross-border trade and investment, distance, time zones, language, culture, government regulation, and differences in business systems and toward a world in which national economies are merging into a single interdependent global economic system (Hill, 2001). The globalization movement has two main components: globalization of markets and globalization of production. Globalization of markets suggests that the boundaries of national markets are breaking down and a single huge market place is emerging. The globalization of production has to do with locating production facilities in optimal world locations.

\section{Inputs and Outcomes of Globalization}

Declining trade barriers and dramatic increases in technology of several types underlie the globalization movement. Lowered trade barriers have produced freer flows of goods, services, and capital investment, while the development of new technology in telecommunications, information processing, and transportation has enabled firms to achieve tight coordination of operations both domestic and in foreign locations (Hill, 2001).

Globalization of markets and globalization of production have led business executives all over the world to increasingly view the world as a single market. Consequently, a number of dramatic changes in the profile of 
international business have occurred. The U.S. share of world output and worldwide foreign direct investment has been reduced dramatically, while major shares of world output and worldwide foreign direct investment are now being attributed to Western European and Southeast Asian economies. Concurrently, a large number of Japanese and European multinationals have emerged. Put in more general terms, globalization of markets and production has accelerated world trade growth, elevated foreign direct investment, and produced more intense competitive pressures in many industries. Additionally, the number of multinational firms is proliferating geometrically as more and more firms are positioned to exploit the opportunities for growth, profit, and market share that globalization seems to promise. With more and more multinational companies seeking shares in the emerging global market, competitive pressures are intensifying and multinational corporations are widening their search for new strategic opportunities with ventures into new countries, cultures, and geographic markets. These new ventures into unfamiliar strategic environments combined with the large increase in the sheer number of multinational companies have resulted in a dramatic increase in the numbers of international company insolvencies and have brought attention to the question of how to deal with transnational bankruptcies. The attention and accompanying debate have to date occurred mainly within the community of legal scholars and the ramifications that these debates hold for business strategists are only now beginning to be recognized as scholars evaluate the strategy implications of this development (Brewerton and LeMaster, 2002).

\section{Emerging Issues}

Two related issues have emerged: (1) the increased necessity for a multinational company to systematically develop contingency strategies in the event that its primary strategy fails and the company becomes insolvent; and (2) the increasing need for a uniform bankruptcy law and court system for resolving international business insolvencies. In regards to the first issue, no company ever intentionally pursues a long term strategic goal culminating in bankruptcy. Companies ordinarily pursue strategies designed to achieve long term goals of profitability, market share, growth, or other similar accomplishments. When strategies for achieving these goals fail, multinational companies may find themselves scrambling to minimize the effects of an insolvency that has completely escaped strategic consideration. Ideally, in the event of insolvency and bankruptcy, contingency planning by strategists will have already determined what bankruptcy law, court, and actions are optimal, and which countries' bankruptcy laws and court system minimize the negative impact of the insolvency as a contingency plan or strategy. There is little in the strategy literature that suggests that multinational company strategists are devoting much attention to the formulation of bankruptcy contingency strategy.

The second emerging issue - the increasing need for a more standardized bankruptcy law and uniform court system for adjudicating transnational insolvencies - is being fueled by debates within the community of legal scholars that center on the determination of the optimal legal solution for resolving international defaults. Guzman (2000) concludes that there are two polar approaches to the adjudication of international insolvencies. These include the Territorialism Model and the Universalism Model. A brief summary of each model follows.

\section{The Territorial Model of Bankruptcy Law}

Territoriality is the idea that each country has the exclusive right to govern within its own borders and is such a basic principle of international law that it is simply accepted as a given or even overlooked. It is the default rule in every substantive area of law including constitutional law, taxation, trademarks, industrial regulation, debt collection and bankruptcy (LoPucki, 2000). In applications of bankruptcy law to multinational companies, territoriality or territorialism means that the bankruptcy courts of a country have jurisdiction over those portions of the company that are within its borders (only) and not those portions that are outside them (LoPucki 2000). Unless there are treaties or other binding conventions to the contrary, countries can only enforce their laws against assets or persons within their own borders. Currently, such treaties or conventions are virtually non-existent and consequently territoriality or territorialism is the international law of bankruptcy today.

If the multinational firm's financial problems are confined to its entities in a single country, the troubled entity or entities either liquidate or reorganize in that country and the multinational's other foreign entities are unaffected. The situation is even simpler in the case of non-multinationals with assets and operations confined 
entirely to a single country. In this simplest case the company would be liquidated or reorganized under the bankruptcy law provisions of the country in which it resides.

When a multinational company's financial difficulties extend across borders, each financially distressed entity files for bankruptcy in each country in which it has significant assets. The effect is to create at least one bankruptcy estate in each country in which significant assets are held. Ideally, in a territorial system the necessary international cooperation takes place in each case. That is, "parallel" bankruptcy proceedings are initiated in each country, and each court appoints a representative for the estate of each entity filing bankruptcy in its jurisdiction. The appointed representatives then negotiate a court-approved solution to the debtor's financial problems that may involve cooperation across international borders. If the estates are worth more in combination than they are separately then economic logic argues that it will be in the interests of the representatives to combine them. Should the negotiators not reach an agreement the assets in each country would be reorganized or liquidated and the proceeds distributed in accordance with the priority rules of each respective country.

\section{The Universalism Model of Bankruptcy Law}

Universalism in its purest form involves the administration of multinational insolvencies by a court applying a single bankruptcy law within the debtor's home country. The two strongest proponents of Universalism are Westbrook (2000) and Guzman (2000). The concept of Universalism as a pragmatic vehicle for resolving multinational bankruptcies is itself complex and is predicated on numerous assumed conditions about the real world.

Westbrook (2000) concludes that there are two elements necessary to a Universalism convention for international bankruptcy. These include a single bankruptcy law and a single forum (court and/or court system) to govern each multinational case. A single international bankruptcy law would create a single set of priorities and method of distribution (of assets) thus ensuring equality for all stakeholders with similar legal rights everywhere in the world. Further, a single law would provide a single consistent set of transfer-avoidance rules that protect all creditors against strategic behavior by debtors and other creditors (Westbrook, 2000).

Similar benefits derive from a single international system of bankruptcy courts. Among other benefits, a single court system applying a single bankruptcy law could reasonably be expected to produce a more consistent set of bankruptcy outcomes with an accompanying high level of predictability. If there were but a single international bankruptcy court (as contrasted to a unified court system), an even higher degree of uniformity, consistency, and predictability would likely be possible. A single court would provide a unified approach to assembly and sale of assets, could more effectively protect those assets prior to sale, and would make prevention or reversal of debtor fraud easier and more certain. This is a particularly urgent need in a world of electronic funds transfer, asset protection trusts, and other devices currently being used to accomplish debtor fraud.

For Universalism to function there must be symmetry between the law and the market in which it operates. This condition requires that the law be capable of covering all or nearly all transactions and stakeholders in the market with respect to the legal rights and duties embraced by the system. Beyond symmetry between the law and the market, Universalism also suggests that there must be convergence of other laws governing creditors' priority, setoff, security interests, debt collection and other related concepts. The primary objection to Universalism as a workable solution to international bankruptcy is political in nature; that is, countries do not favorably view the idea of relinquishing their sovereignty in respect to any issue or area of law. Therefore, pure Universalism is unlikely to be achievable in the foreseeable future (Westbrook, 2000). But Westbrook (2000) also argues that the linking mechanism that brings about symmetry and convergence of related laws is the emergence of the global market, citing initiatives from the International Monetary Fund and the World Bank; recently rewritten bankruptcy laws in Germany, Argentina, Australia, Canada, Japan, Russia, China, and most of Eastern Europe; the emergence of new bankruptcy laws in Singapore, Indonesia, and Thailand; additional ongoing bankruptcy reform efforts in Japan, Great Britain, and Mexico; the promulgation of a Model Law on Cross Border Insolvency by the United Nations Commission on International Trade Laws (UNITRAL); and initiatives within the European Union and NAFTA countries that provide for closer coordination of transnational bankruptcy procedures. The revisions, changes, and 
initiatives cited above are all based on extensive examinations and analyses of other countries' bankruptcy laws and reform proposals (Westbrook, 2000).

\section{Bankruptcy Laws and Universalism in Selected Latin American Countries}

In an earlier study, seven Latin-American countries' bankruptcy laws were analyzed and compared to determine their basic provisions, the commonality of their provisions (vis a vis their convergence toward the Universalism Model), and their relative attractiveness to strategists (Brewerton and LeMaster, 2003). The seven countries' laws differed in several regards and details, but also manifested some degree of uniformity and convergence predicted by Westbrook (2000) and supported by the Universalism school within the community of legal scholars (Brewerton and LeMaster, 2003). Four provisions of bankruptcy law were identified as being of common interest to strategists. These include provisions for (a) possible reorganization; (b) a period of conciliation; (c) trigger conditions; and (d) criminal conduct provisions. In their study of Latin American country bankruptcy laws, Brewerton and LeMaster found that three of the seven countries had reorganization provisions in their laws, three of the seven countries provided a conciliation period, six of the seven countries had criminal conduct penalties, and all seven had some form of trigger condition. Based on the provisions included in their laws and the perceived behavioral preferences of strategists, Brewerton and LeMaster (2003) were able to rank order the countries' laws in order of perceived preference by strategists as well as draw general conclusions concerning these countries' progress toward a common or universal bankruptcy law.

\section{Conditions for Entry into the European Union}

Since the European Union was created in the 1950's with 6 members, it has been enlarged to the current 15 countries (Austria, Belgium, Denmark, Finland, France, Germany, Greece, Ireland, Italy, Luxembourg, Portugal, Spain, Sweden, The Netherlands, United Kingdom). There are 10 new member States (Cyprus, Czech Republic, Estonia, Hungary, Latvia, Lithuania, Malta, Poland, Slovakia, and Slovenia) that will join the EU in 2004 and 3

applicant countries (Bulgaria, Romania, Turkey) applying for membership (http://europa.eu.int/abc/governments/index_en.htm). As a condition of membership, all new members to the EU are required to equilibrate the rules and policies of their own countries to those of the EU (http://europa.eu.int/comm/; http://europa.eu.int/comm/ ) with the purpose of the EU "to organize, in a manner demonstrating consistency and solidarity, relations between the Member States and between their peoples" and as set forth in the TITLE I Common Provisions for the European Union (http://europa.eu.int/ab/obj/treaties/en/entr2b.htm).

The Common Provisions include six separate articles which collectively prescribe the purpose of the EU, its objectives, its institutional framework, its general political guidelines, its exercise of powers and its guarantees of the principle of democracy and protection of human rights. Since the Treaty on European Union was signed in 1992 in Maastricht there have been several conventions that have added additional criteria for member states. The article "The European Union: Still Enlarging" (European Commission Library Catalogue ECLAS, 2001) notes that at the 1993 Copenhagen European Council (EU Summit) the "Copenhagen criteria" for EU members were presented. These criteria require "stability of institutions guaranteeing democracy, the rule of law, human rights and respect for and protection of minorities; the existence of a functioning market economy as well as the capacity to cope with competitive pressures and market forces within the Union; and the ability to take on the obligations of membership including adherence to the aims of political, economic and monetary union."(8)

In 1995 The Madrid European Council noted that an applicant country to the EU "should adjust its administrative structures, so that EU legislation is not only adequately transposed at the national level, but is also implemented effectively through appropriate administrative and judicial structures as a prerequisite of the mutual trust required by EU membership"(European Commission Library Catalogue ECLAS, 8).

In 1999 the Helsinki European Council added that candidate countries "must share the values and objectives of the European Union as set out in the Treaties" urging "candidates to resolve outstanding border disputes, and emphasized the importance of high standards of nuclear safety." The 2000 Nice European Council 
requested applicant countries "to continue and speed up the necessary reforms to prepare themselves for accession" (European Commission Library Catalogue ECLAS, 8).

\section{Provisions and Agreements Affecting Bankruptcy in Europe}

From a multinational business strategist's point of view, a single universal bankruptcy law (Universalism) is generally preferable to different bankruptcy laws in each separate country with heterogeneous provisions (Territorialism). Westbrook (2000) suggests that economic integration and trade agreements and blocs such as NAFTA and the EU are a contributing force in the trend of convergence of bankruptcy laws toward Universalism.

In forging a successful economic integration of countries many issues must be resolved, including differing political backgrounds and climates, differing economies, human rights, and consumer and environmental protections; the process of bankruptcy is broadly included in these issues. Intuitively, the concept of a large union of economically integrated countries suggests an approach to resolving multinational insolvencies that is based on either (a) a common, universal bankruptcy law and court system for the entire economic union; or (b) bankruptcy laws in the member countries that contain provisions which have a high degree of similarity, parallelism, or commonality. Both of these situations would be more closely associated with the Universalism Model than with the general Territorial Model of bankruptcy.

The "European Convention on Certain International Aspects of Bankruptcy" (ETS NO.136) (http://conventions.coe.int/treat/en/summaries/html/136.htm) is a treaty that provides for the following mechanisms:

1. The Convention offers two possibilities when the bankrupt's assets are located in more than one state:

a. It enables liquidators appointed in the State in which a bankruptcy is opened to exercise some of their powers (administration, management and disposal of the debtor's assets) directly in the country in which the bankrupt's assets are located. Liquidators must, in such a case, comply with the national law of the State in which they intend to act.

b. $\quad$ It allows the opening of secondary bankruptcies. A secondary bankruptcy can be opened in any other Party in which bankrupts possess assets, without any need for their insolvency to be established, the main bankruptcy will be enough. The secondary bankruptcy is governed by the national law of the State in which it is opened.

2. When the creditors are spread over several States, the Convention provides for measures whereby they may be informed, and so enabled, to lodge their claims in the bankruptcy opened in another State in a straightforward manner and with few formalities (http://conventions.coe.int/treat/en/summaries/html/136.htm).

The European Convention also recognizes that there are differing laws regarding insolvency among the various members of the EU and that the primary goal of insolvency is to be "the optimal use of a debtor's assets in the interest of the creditors..." (conventions.coe.int/treat/en/Reports/136.htm). The summary provisions of the European Convention seem to suggest that collaborating countries' collective bankruptcy laws are more consistent with the philosophy of the Territorialism Model than with the Universalism model of bankruptcy.

\section{Bankruptcy Laws in New Member Countries}

Much of the information regarding insolvency and bankruptcy laws for countries making the transition to EU membership has been difficult at best to acquire. It is not always possible to get the same types of information about each country and the accuracy and reliability of the information cannot be guaranteed. To the extent possible for comparative purposes, the status of bankruptcy laws for the 10 new member states is presented here. Should the bankruptcy laws of these countries evolve and converge, it is expected that strategists will have a greater attraction 
for groups of countries that have bankruptcy laws that converge toward Universalism and less attraction for countries that maintain individual bankruptcy laws with few or no similarities.

Cyprus

In June, 2003 the decision was made by the House Legal Affairs of the Cyprian government to forego discussions on new bankruptcy laws until the fall. The reasons given were that because the laws are so antiquated (the relevant laws were written in 1931), it will take some time and careful in-depth study before changes can be suggested. In Cyprus, there is no provision in the current laws for a company to restructure, reorganize, or otherwise have the opportunity to continue in business. Under current laws in Cyprus bankruptcy once experienced remains a lifelong condition. The importance of developing standardized laws more in line with the laws of the EU cannot be overstated from the perspective of the amount of business that takes place in Cyprus. For example, Cyprus is reported to be among the world's most important shipping nations (http://www.cyprus-mail.com; http://europa.eu.int/comm/ ).

Those looking to revamp the old laws are looking to bankruptcy as a legal procedure rather than a life punishment. Under current laws anything and everything can be sold including personal possessions of the debtor. The new laws will be modeled after the UK system and are expected to provide for monetary limits, criminal intent, and some form of reorganization.

\section{Czech Republic}

Before national reorganization, Czechoslovakia had a long history of industrialization and was among the top developed industrial states in the world (http://europa.eu.int/comm/). But because of the Communist system, state-owned companies never went bankrupt or were even allowed to restructure.

Like Cyprus, there is no accommodation for bankrupt companies to restructure or reorganize in some way to prevent liquidation. But unlike Cyprus, because of the extremely complicated and ineffective bankruptcy laws, insolvent companies never get to the point of bankruptcy. The current law (passed in 1991 but founded on preWorld War II statutes) provides little resolution for debtors or creditors (Vesely, 2003). Like Cyprus, all assets can be seized and sold possibly leaving all involved with little to no assets.

The developing new laws in Cyprus that are necessary to be considered for membership in the EU give some of the control for the proceedings to the creditors or business managers rather than appointing a lawyer as the trustee of the account. A lawyer's interests are much different than those of a creditor, wanting to sell off assets and close out the company as quickly as possible rather than having the best interests of the creditors and the debtor in mind. The new laws once developed may eventually allow for composition giving the debtor and creditor an opportunity to resolve the debt dispute without assistance from the court. Because bankruptcy was simply not something anyone cared about under the state-owned system, there was no political will to change the laws. Becoming a member of the EU provides both the political urgency and economic need to initiate changes in the bankruptcy laws (http://www.vpp.cz/uk/97 05.htm ; http://www.mujweb.cz/www/vaske/kv.htm ).

The bankruptcy act of 1991 makes everyone involved in the insolvent company liable. The applicant for bankruptcy must pay a deposit of up to 50,000 Czech Republic crowns that will be paid to the debtor should the claim be dismissed. If a creditor files the application, the debtor can make a request for protection from the court for a period of 3 months. The estate of an insolvent firm includes the property of all those affiliated with the firm, making everyone liable. The 3 month protection period would allow the debtor time to get organized for a defense against the claim (ACT of the Czech Republic; http://www.vpp.cz/uk/97_05.htm ; http://www.mujweb.cz/www/vaske/kv.htm ). 
Estonia

Estonia is one of the three Baltic States that separated from Russia just in time to prevent total extermination. The Baltic nations of Estonia, Lithuania and Latvia under Soviet rule were disallowed their national identity including their language. Estonia, unlike its Baltic neighbors, is exceedingly aware of its Scandinavian neighbors, especially Sweden, and may be motivated to follow Sweden's footsteps by joining the EU (Baltic States, 1995; http://europa.eu.int/comm/ ). Lithuania and Latvia look more to the West than to the North for role models and political guidance.

In Estonia a firm can be considered insolvent when a debtor has not paid a debt within 10 days after the expiration of a date for payment. An application for insolvency must be heard within 30 days to 2 months of application, and as is the case for many countries, a claim of insolvency can be filed by either the debtor or a creditor (http://www.legaltext; Kowalski, et al 2003). As with the Czech Republic, the creditor can be assessed a fine if a false bankruptcy petition is filed against the debtor.

\section{Hungary}

Hungary is a 1,000 year old state which was host to "an armed revolution against Stalinism, and of the dismantling of the Iron Curtain" (http://europa.eu.int/comm/ ). A major difference between the Baltic states of Lithuania, Latvia, and Estonia and their post-communist counterparts of Poland, Hungary, Czech Republic, and Slovakia is that these later countries, although also repressed by the Soviets, did not suffer the near genocide of the Baltic States.

In Hungary a debtor must have the assistance of a lawyer when filing for bankruptcy proceedings. Claims can take from 3-4 months (if they are undisputed) to as long as 2-4 years (if they are disputed). Hungary requires a lawyer be engaged for insolvency claims so the costs to the debtor of an insolvency application can be from $3 \%$ to $6 \%$ of the claimed amount plus the fees of the lawyer.

Either the debtor or any creditor can file the application for bankruptcy and in the case of a creditor filing, the creditor may choose to have a lawyer represent them. The new bankruptcy law, similar to the U.S., and enacted January 1, 1992 has an automatic trigger requiring that any entity in arrears over 90 days must file for reorganization or liquidation within 8 days (Gray, et al 2000). This new law has resulted in bankruptcy filings in excess of 25,000 which to the surprise of many were resolved fairly quickly. Gray, et al (2000) note this is probably due to the courts having little role in the proceedings once a case was approved. Hungary has a provision for composition which allows for the debtor and creditor to come to an agreement for resolution of debts without going through the court. After enactment of the new law the greatest delay in completing the bankruptcy process has been when a debtor liquidated rather than reorganized.

Latvia

Latvians display a very solid, reliable work ethic most probably held over from the German influence (Baltic States, 1995). This characteristic may contribute to Latvia's desire to join the EU. But, unlike its Baltic neighbors, Latvia showed much less resistance to its Russification. This is evidenced by the fact that only $54 \%$ of Latvia's population has remained Latvian (Baltic States, 1995).

Latvia's fairly fluid or less structured bankruptcy laws may be a result of this lack of resistance to the former Communist system. For example, under Latvia's current bankruptcy law there is no specific time frame for a firm to be insolvent. If the firm has not met its obligations for a "long time" then virtually anyone - debtor, creditor, friend, relative, or other interested parties - may file a petition for insolvency on the firm. The current law provides for a rather elaborate arrangement or guideline on the amounts of restitution anyone can receive and although there is criminal liability for fraudulent behavior there is no incarceration required. If a plan for restoration is accepted, the time frame for achieving restoration cannot exceed two years (http://www.ttc.lv/New/lv/tulkojumi/E0146.doc ; 
The Parliament of the Republic of Latvia, Translation 2001; http://www.baltictrade.lv/files/ Law\%200n\%20the\%20Insolvency\%20of\%20Undertakings\%20and.pdf ).

\section{Lithuania}

Poland is sometimes considered the colonizer, or at least historical partner of Lithuania (Baltic States, 1995). This national desire not to be outstripped economically by Poland may be part of what drives Lithuania to become a part of the EU. Additionally, the United States plays a prominent role in influencing the political and economic development of Lithuania. But one of the political problems with the post-communist countries and bankruptcy laws is the fact that "statehood" has had to be re-learned and politics and politicians are not held in high esteem even today. These countries are only now starting to vote from office corrupt politicians and others in positions of power and trying to manage organized crime. The opportunity to join the EU opens the doors for economic and political freedom these countries have not experienced in decades.

There are several interesting and significant provisions in Lithuania's current bankruptcy law. If a firm's liabilities exceed half the value of the firm's assets and the firm does not resolve its debts to its creditors within 3 months, the firm is considered insolvent. There are five conditions under which a petition for bankruptcy can be filed and only one of these five conditions must be met. The conditions include the following: if wages are not paid when due, if goods or services are not paid when due, if taxes or other compulsory contributions are not paid when due, if the firm makes a public announcement that it intends not to pay when due, or if the firm has no income or assets from which debts could be paid. The debtor, an administrator, board member, or any creditor is eligible to initiate a bankruptcy proceeding. There are many articles that describe the liability of the individual filing the bankruptcy petition. If a creditor files the creditor must notify the debtor in writing and must set at least a 30-day period for the debtor to discharge the liabilities. There is no apparent incarceration if criminal behavior is found (http://www3.lrs.lt/c-bin/eng/preps2?Condition1=136576\&Condition2 ;Republic of Lithuania, 2003).

Malta

People have lived in Malta for 7,000 years but Malta has only been an independent state since 1964. Since independence the country has developed many sectors to its economy including tourism, finance, transportation, and "a manufacturing sector including high-tech electronics" (http://europa.eu.int/comm/).

Malta defines "state of bankruptcy" as any "trader" who suspends payment of his debts, but there is no specific relationship to how long payments have been suspended or the percentage of debt (Commercial Code, 2002). As in the Czech Republic, whoever initiates the bankruptcy petition must pay a deposit for the proceedings, and the bankrupt entity is given an "allowance" on which to live until the process is completed. In Malta, immediate family members can not seek a declaration of bankruptcy against each other and when a "trader" is bankrupt they are jailed but may ask for a temporary release for up to 6 months provided there is no evidence of intentional deceit or fraud (Commercial Code, 2002; http://docs.justic.gov.mt/lom/legislation/english/leg/vol_2chapt13.pdf ). Malta does provide for composition which is the opportunity for the debtor and creditor to come to an agreement for the settlement of the claim without going through the court. When composition is approved the "trader" is considered no longer bankrupt and can return to the administration of all his property. If for some reason composition is approved but the "trader" defaults then this would be considered a new bankruptcy and the process would start all over (Commercial Code for Malta; http://docs.justic.gov.mt/lom/legislation/english/leg/vol_2chapt13.pdf).

Poland

Poland is the largest country seeking entry into the European Union. Because it is considered at the crossroads of the North-South and East-West routes in Europe it is among the "world's most dynamically growing markets" and has a major role in Europe's cultural development (http//:www.poltradeindia.org/operating_in_poland.htm ; (http://europa.eu.int/comm/). 
Until the laws governing insolvency changed in 1991, Poland had relied on laws written before WWII. "The unshackling of market driven mechanisms in Poland has provided challenges to corporate management" and companies are now having to rely on their own managerial expertise and resource to become profitable and competitive (http://www.masterpage.com.pl/outlook/insolven.html ). Reforms in the laws continue to be debated. Interestingly, the President's legal ordinances dating back to 1934 are still the legal basis for bankruptcies (Hermes Facts, 2002). Towns and municipalities, including universities and special public sector entities like railway companies, because of their explicit exclusion from one of the Articles, cannot be declared bankrupt (Hermes Facts, 2002). Some of these state owned entities have become privatized as a result of market forces.

Poland's laws concerning bankruptcy and composition are much like most former Communist countries in terms of being detrimental to creditors (Paczynski, 2003). Applicants filing for bankruptcy in Poland must be represented by either members of the board or by a lawyer. Applicants can be either creditors or debtors. The length of time it takes to bring the proceedings to resolution can be from 4 months to 3 years depending on whether the claim is disputed or not and the costs can range from $13 \%$ to $21 \%$ of the outstanding claims (Bankruptcy Law of the Republic of Poland). Like Hungary, Poland provides for composition allowing the parties to resolve the insolvency claim outside the court. If fraud is determined "penal sanctions ranging from three months to five years of incarceration" can be imposed (Paczynski, 2003). Additionally, if a debtor's obligation does not exceed 10\% of the balance sheet, and it has not been longer than 3 months since the debts have been paid, the court can dismiss the bankruptcy petition (Paczynski,2003). According to Coface Intercredit Holding AG (2003) new laws regarding bankruptcy and composition proceedings will go into force sometime in 2003.

\section{Slovakia}

Slovakia, has only been a country since 1993, but it has a rich history as part of the center of Europe and as the former seat of the Hapsburg Empire (http://europa.eu.int/comm/). Modern laws of any kind are relatively new to this young and small country.

In Slovakia, a lawyer is not required for a bankruptcy hearing. A creditor may choose to represent himself or he may enlist the services of a lawyer. Either the creditor or the debtor is eligible to file a petition for insolvency and it never takes less than 18 months to complete a proceedings. A single judge conducts all of the proceedings and makes all the decisions regarding the bankruptcy. The costs for conducting a bankruptcy proceeding is the outstanding amount claimed plus legal fees up to $10 \%$ of the outstanding amount. If bankruptcy is filed and rejected, another petition can be submitted after six months. Essentially a debtor or creditor could petition for bankruptcy every six months until the petition is accepted. Also, if there are not enough assets to pay for the proceedings of a bankruptcy, a proceedings cannot be filed (http://Gild\%20G\%20User:password@wbln0018.worldbank.org ). Once a bankruptcy is filed, if the debtor should die, the bankruptcy proceedings stop.

Regarding the issue of fraudulent activity, there appears to be no punishment such as incarceration. The creditors, however, can demand full payment on their claim and "within three years from the effective date ... any creditor may file an action with the court ... to receive full payment..." [unless] the creditors were involved in the fraud (http://Gild\%20G\%20User:password@wbln0018.worldbank.org). The Slovakian laws do provide for composition allowing the debtor and creditor to come to an agreement on a resolution for the amount owed.

\section{Slovenia}

According to the Slovenian Economic Mirror (1999) there was a slowing down in the total number of bankruptcies and reorganizations in Slovenia from 1996 to 1997. Companies in Slovenia tend to restructure rather than become insolvent through a process referred to in a coined phrase called "defensive restructure." As a result there has been a "large number of "clinically dead' companies ..." weighting down the healthy side of the business sector (Slovenian Economic Mirror 1999). In addition, because of the Communist philosophy that still permeates the country, the state-owned companies, most of which are suffering great losses, continue in business. An interesting dynamic has resulted for the new private companies. These companies have much different problems 
resulting from the need to compete while applying budget and resource restrictions. The banks are less tolerant of these new companies because they have not dealt with these types of business entity problems in the past. So the newly founded private sector is wedged between the lack of experience of the governing entities and the "cleansing process" that has been taking place since independence.

In bankruptcy proceedings Slovenia requires a lawyer to represent the creditor. Either a creditor or the debtor can file for bankruptcy and unlike the other countries, Slovenia provides only for bankruptcy proceedings rather than for composition or reorganization procedures. Proceedings can take from 1 to 4 years and with costs from $4 \%$ to $30 \%$ of the outstanding debts. Bankruptcy proceedings are conducted through the court system while reorganizations are settled out-of-court which probably helps explain the overall increase in reorganizations and the decrease in bankruptcies.

The Financial Operations of Companies Act of Slovenia outlines the laws regarding insolvency. That Act requires that a company perform "....in such a manner that, at all times, it shall be able to fulfill its liabilities in due time and that it shall be continuously able to fulfill all its liabilities" (Article 5). The Financial Operations of Companies Act tends to give much direction in terms of what companies are expected to do. For example, Article 7 is entitled Liquidity Management and offers guidelines such as planning, monitoring, and controlling liquidity as good management practices. Article 9 focuses on good practices for monitoring and hedging against risks. The entire document is written with a tone of guiding and facilitating a process rather than a tone of failure and punishment.

\section{Conclusions}

The purpose of this paper has been to comparatively analyze the new EU member states' bankruptcy laws to determine their relative similarities or lack thereof and to assess the implications that this comparative analysis poses for multinational company strategists. The analysis of the new member countries' bankruptcy laws produced a number of conclusions.

First of all, the status of these countries' laws may best be described as fluid. Little similarity or commonality of provisions is apparent. The few common elements manifested by the collective group of laws seem trivial in nature (for example, the required use of lawyers, who can initiate a bankruptcy filing, whether composition is permitted, etc.), and the degree of commonality of these provisions from country to country is sporadic rather than consistent. The current absence of systematic similarities in new member states' bankruptcy laws may dissipate over time as new member states develop new bankruptcy laws or modify existing laws in the interest of achieving greater convergence of bankruptcy laws across the breadth of EU countries. But it is eminently clear that the current status of these new member states' bankruptcy laws is developmental and the transitional nature of these laws creates an enormous degree of uncertainty for multinational company strategists regarding the development of contingency strategies centered on the possibility of insolvency and bankruptcy proceedings. Multinational company strategists would be well advised to proceed very carefully regarding the development of strategic initiatives in these new member countries because of the attendant uncertainties associated with the transitional nature of the bankruptcy laws. Closely monitoring the continuing development of these laws is highly recommended.

A second conclusion is that the various treaties and agreements prescribing the conditions that must be met for membership in the EU are somewhat misleading regarding the degree of commonality expected of member states' bankruptcy laws. Multinational company strategists should avail themselves of specialized legal expertise in assessing the degrees of similarity and commonality that different new member states' laws manifest. The six separate articles in the Title I Common Provisions for the European Union, the Copenhagen criteria requiring "...stability of institutions guaranteeing democracy, the rule of law,...", the provisions of the Madrid European Council requiring an applicant country to "... adjust its administrative structures so that EU legislation is not only adequately transposed at the national level, but is also implemented effectively through administrative and judicial structures...", the provisions of the Helsinki European Council and the Nice European Council, all speak (generally) to the need for similarity and commonality in both administrative and judicial matters, including the bankruptcy 
process. Multinational company strategists should not be taken in by the general and misleading language of these documents, but should rely instead on specialized legal expertise for a more meaningful and realistic assessment of the practical challenges and difficulties associated with bankruptcy proceedings in new member countries. In summary, despite the language contained in the treaties and agreements governing EU membership, this study confirms that the administrative and judicial requirements in actuality are so general that little similarity or commonality of bankruptcy law provisions exists across new member countries.

A final conclusion of this study focuses on the relationship the new member countries' laws bear to the Universalism Model and the Territorial Model of bankruptcy law. The new member countries' laws are clearly aligned with the Territorial Model of bankruptcy law. In spite of the language contained in several subsequent treaty and convention documents, the European Convention on Certain International Aspects of Bankruptcy continues to be the most authoritative statement of the mechanisms of bankruptcy law in EU member countries. The European Convention clearly and articulately confirms that all bankruptcy petitions and eventual resolutions must comply with the national laws of the sovereign states in which they are processed. Given the heterogeneous nature of the collective bankruptcy laws of member nations at this time, one must conclude that the Territorial Model of bankruptcy law currently reigns in the E.U., and there is little evidence at this time of a trend toward convergence and the Universalism Model.

\section{References}

1. ACT of the Czech Republic No. 328/1991 Sb. On bankruptcy and composition. The Federal Assembly of the Czech and Slovak Federal Republic.

2. Bankruptcy Law of the Republic of Poland

3. Brewerton, F.J. and J. LeMaster (2002) "Emerging models of international bankruptcy law: strategic implications for multinational companies". International Business and Economics Research Journal (1)10: $1-9$.

4. Brewerton, F.J. and J. LeMaster (2003) "Toward universalism in international bankruptcy law: foundations for strategy formulation in selected countries" Journal of Business and Economics Research (1)9: 97-108.

5. Coface Intercredit Holding AG (March, 2003) Facts and figures on legal proceedings in central and eastern European countries".

6. European Commission Library Catalogue ECLAS, 2001 (http://europa.eu.int/eclas/cgi/)

7. "European Convention on Certain International Aspects of Bankruptcy" (ETS no.136) (conventions.coe.int/treat/en/Reports/136.htm)

8. Gray, C, S. Schlorke, M Szanyi (2000) Hungary's bankruptcy experience, 1992-93. Policy Research Working Paper 1510.

9. Guzman, A.T. (2000) International bankruptcy: in defense of universalism. Michigan Law Review (98)7: 2177-2215.

10. Hermes Facts (2002) Polish insolvency law.

11. Hill, C.W.L. (2001). Global Business. Boston: Irwin McGraw-Hill.

12. Kaiser, K.M.J. (2001) European bankruptcy laws: implications for corporations facing financial distress. Financial Management, 25(3): 67-85.

13. Kowalski,T, E. Kraft, A. Mullineux, V Vensel, C Wihlborg (2003) Bankruptcy procedures, corporate governance and banks' credit policy in Croatia, Estonia, and Poland. Working paper presented at the $9^{\text {th }}$ Dubrovnik Economic Conference, June, 2003.

14. LoPucki, L.M. (2000) The case for cooperative territoriality in international bankruptcy. Michigan Law Review (98): 7, 2216-2251.

15. Psyllides, G (2003) Bankruptcy law left to wait until the autumn. Cyprus Mail. http://www.hri.org/news/Cyprus/cmnes/2003/03-06-27.cmnews.html.

16. Slovenian Economic Mirror (1999) Part IV structural and institutional reforms

17. Vesely, J. (2003) Wanted: new bankruptcy laws not more bankruptcies. http://www.vpp.cz/uk/97_05.htm

18. Westbrook, J.L. (2000) A global solution to multinational default. Michigan Law Review (98):7, 22762328.

19. Williams, Roger (ed) Baltic States (1995) Boston: Houghton-Mifflin Company. 
20. http://europa.eu.int/abc/governments/index en.htm

21. http://europa.eu.int/abc/obj/treaties/en/entr2b.htm

22. http://conventions.coe.int/treat/en/summaries/html/136.htm

23. http://www.legaltext.ee/en/andmebaas/ava.asp?tyyp=SITE_ALL\&ptyyp=1\&m=000\&query=bankruptcy+ac t\&nups. $x=29 \&$ nups. $y=7$

24. http://www.cyprus-mail.comhttp://europa.eu.int/comm/

25. http://www.vpp.cz/uk/97_05.htm

26. http://www.mujweb.cz/www/vaske/kv.htm

27. http://www.ttc.lv/New/lv/tulkojumi/E0146.doc

28. http://www.baltictrade.lv/files/ Law\%20On\%20the\%20Insolvency\%20of\%20

29. http://www3.lrs.lt/c-bin/eng/preps2?Condition1=136576\&Condition2

30. http://www3.lrs.lt/c-bin/eng/preps2?condition1=136576\&condition2Office of Seimas of the Republic of Lithuania (2003).

31. http://www.vpp.cz/uk/97 05.htm

32. http://www.mujweb.cz/www/vaske/kv.htm

33. http://docs.justic.gov.mt/lom/legislation/english/leg/vol 2chapt13.pdf Commercial Code for Malta (2002)

34. http//:www.poltradeindia.org/operating_in_poland.htm

35. http://Gild\%20G\%20User:password@wbln0018.worldbank.org

36. http://www.masterpage.com.pl/outlook/insolven.html 